\title{
大型商業施設が地域の核となるための行政の支援に関する研究 STUDY ON SUPPORT OF ADMINISTRATION FOR LARGE-SIZED COMMERCIAL ESTABLISHMENT TO SERVE A CORE OF THE AREA
}

平田圭子*，菅原辰 幸**

Keiko HIRATA and Tatsuyuki SUGAHARA

\begin{abstract}
It is shown clearly whether administration can support large-sized commercial establishment for large-sized commercial establishment to serve as a core of the area.

The view of administration

- Large-sized commercial establishment becomes a core of the area.

- Support of administration will increase a possibility that it will become a core of the area more.

- The expense which administration pays decreases because administration invests jointly to large-sized commercial establishment.

- It is hard to carry out support of administration with an organization, a staff, cost, an ordinance, etc.
\end{abstract}

Keywords : Large-sized commercial establishment, administration, support,Supermarket, Area 大型商業施設, 行政, 支援, スーパーマーケット，地域

\section{1. はじめに}

少子高齢化に起因するだけではなく, 2011 年 3 月 11 日に発生し た東日本大震災によっても, 地域住民相互の慗がりの大切さが再確 認された。その地域住民相互の繋がり方は, 高層マンションが立ち 並ぶ都心と戸建の住宅が増える郊外における居住形態によっても異 なるが，最寄品などの買い物を地域に増えてきている大型商業施設

(大型商業施設の本研究における定義を表 1 に示す。)にて購入する 時に,他の地域住民との交流の可能性の接点を両者は持ち得ている。 大型商業施設は週に 1 回以上は多くの地域住民が共通に訪れる場所 であり，会話が生まれるところである。大型商業施設の敷地面積も 様々だが，この場所を地域の核として，他機能を付加したり，イべ ントを開催したり, 行政がこれら既存の施設を有効に活用し, 積極 的に活用することのメリットはあるのではないだろうか。

本研究は，大型商業施設が地域の核となるための行政の支援につ いて，行政側の思惑の一部を明らかにすることを目的とする。

既往研究には次のものがある。丁・近藤らの「地方都市における 消費者の買物意識と行動の分析」 ${ }^{1)}$ は，地方都市において高齢者と
表 1 大型商業施設の本研究における定義

\begin{tabular}{|c|c|}
\hline 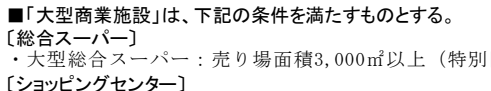 & 政令指定都市は、 $6,000 \mathrm{~m}^{2}$ 以上 \\
\hline $\begin{array}{l}\text { ・ネイバーフッド型: 売り場面積 } 5,000 \mathrm{~m}^{2} \sim 15,000 \mathrm{~m}^{2} \\
\text { ・コミュニティ型 } \quad: \text { 売り場面積 } 6,000 \mathrm{~m}^{2} \sim 18,000 \mathrm{~m}^{2}\end{array}$ & 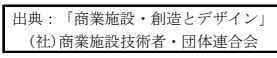 \\
\hline $\begin{array}{l}\text { 口「地域の核」は下記とする。 } \\
\text { ・近隣住民交流の場を提供する施設 }\end{array}$ & \\
\hline
\end{tabular}

非高齢者に注目し買物意識と行動特性を把握することを目的とし, 実際の買物時の移動距離と買物における満足距離を考察している。 曽根らの「高齢者の交流の場としての近隣型小売商店の役割－1960 年代のミニ開発住宅地における近隣コミュニケーションに関する研

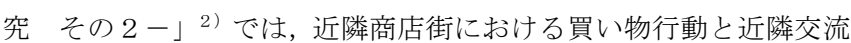
との関係を商店利用客と地域住民の両面調査で把握し, 近隣商店が 高齢者層にとって生活上必要なだけでは無く，近隣居住者との交流 機会の場を提供する機能を持つ物であることを示唆している。本研 究は，大型商業施設を対象とし，地域の核となるための可能性を行 政の支援から探っていることが，それらの研究とは大きく異なる。
* 広島工業大学環境学部 准教授 $\cdot$ 博士 (工学)

** 広島工業大学環境学部 教授・工学博士
Assoc. Prof., Faculty of Environmental Studies, Hiroshima Institute of Technology, Dr. Eng. Prof., Faculty of Environmental Studies, Hiroshima Institute of Technology, Dr. Eng. 


\section{2. 研究方法}

表 2 に示すように，地域住民の繫がりを特に求められている高齢 者が多い地域, つまり内閣府の「平成 24 年 都道府県高齢化率の推 移」において, 高齢化率上位 10 位中 5 県（島根県：2 位, 高知県： 3 位, 山口県 : 4 位, 徳島県 : 8 位, 愛媛県 : 9 位) を含む, 中国・

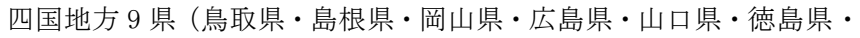
香川県・愛媛県・高知県）の各市役所 92 箇所を対象にアンケート調 查を実施（2011 年 11 月 15 日）した。

郵送先の部署は, まちづくりに関わる部署を各市役所の HP から確 認し, 依頼文に郵送先部署以外に適切な部署がある場合には転送し てもらえるように記載した。

アンケート内容は， 1 。 大型商業施設が地域の核となりえる, 現 在行政が行っている支援，2. 行政と大型商業施設との共同出資， 支援に対する提案（ここでの共同出資は，企画を大型商業施設と共 に行い金銭的な出資をすること，支援は人的支援などとする。以下 同様)，3. 大型商業施設と共同出資，支援したときの行政側のメリ ット，4. 大型商業施設と共同出資，支援の方法，5. 大型商業施 設の可能性，についてである。なお，組織の回答では無く個人の意 見として回答する場合は，そのことを記載してもらった。

\section{3. 研究結果}

アンケートの回収結果は, 配布数: 92 , 返信数 32 , 回収率: $34.7 \%$ であった。

\section{1 行政が行っている事業・支援}

大型商業施設が地域の核となりえるために現在行政が地域住民の ために行っている人的, 金銭的 (交付金等), 物的支援を含む全てに ついて, 各市役所ホームページ（以下，HP）から調査を行い，図 1 に示すように分類 ${ }^{3)}$ された。行政支援は, 大きく「非日常生活」と 「日常生活」に分けられる。「非日常生活」は “祭り・イベント等”, “防災・災害等”,「日常生活」は “地域・環境等”, “世代・属性 等別”，“分野等別”，“その他”にさらに分類された。それらに 属する具体的な詳細は 11 に分類された。A:年中行事・祭事（お祭 り等), B:伝統文化（展覧会等), $\mathrm{C}$ :音楽イベント (音楽祭, コンク 一ル等), D: スポーツ関連 (市民運動会等), $\mathrm{E}$ :防犯・清掃（防犯パ トロール，清掃プロジェクト等）, $\mathrm{F}$ : 子育て世代向け（食育等）, G: 若者向け（定住支援，婚活パーティ等）, H:障害者向け（イベント， 教育相談等), I: 人材育成 (ボランティア育成, 起業セミナー等), J:IT 関連（パソコン教室，アプリ制作セミナー等），K:その他。

これらの支援の中で, “行政が単独で行っている事業・支援” と“行 政が市民または企業と協働で行っている事業・支援”の比率を図 2 に示し比較する。

“行政が単独で行っている事業・支援” の方が多い項目は, C:音 楽イベント（音楽祭，コンクール等） 10\%>9.7\%（前記の\%に行 政単独で行っている事業・支援の比率，後記の\%に行政が市民また は企業と協働で行っている事業・支援の比率を記す。以後同椂。）, $\mathrm{G}$ : 若者向け（定住支援，婚活パーティ等） $10 \%>7.8 \%$, J:IT 関連 (パソコン教室，アプリ制作セミナー等） $6.3 \%>5.2 \%, \mathrm{~K}$ :その他 $5 \%>1.3 \%$ であり，“行政が市民または企業と協働で行っている事 業・支援”の方が多い項目は，A:年中行事・祭事 (お祭り等) $10.6 \%$ $<12.3 \%$, B:伝統文化（展覧会等） $10 \%<11.6 \%$, D:スポーツ関連 （市民運動会等） $12.5 \%<12.9 \%, \mathrm{E}$ :防犯・清掃（防犯パトロール，
表 2 アンケート郵送市役所配布・返信数・回収率

\begin{tabular}{|c|c|c|c|c|c|c|c|c|c|}
\hline 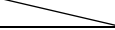 & 鳥取県 & 島根県 & 岡山県 & 広島県 & 山口県 & 德島県 & 香川県 & 愛媛県 & 高知県 \\
\hline 配布数 & 4 & 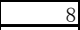 & 15 & 14 & 13 & 8 & 8 & 11 & 11 \\
\hline 返信数 & 1 & 5 & 4 & 6 & 4 & 4 & 2 & 3 & 3 \\
\hline 回収率 & $20 \%$ & $38 \%$ & $21 \%$ & $30 \%$ & $24 \%$ & $33 \%$ & $20 \%$ & $21 \%$ & $21 \%$ \\
\hline 有効回答率 & & & & & & & & & $100 \%$ \\
\hline
\end{tabular}

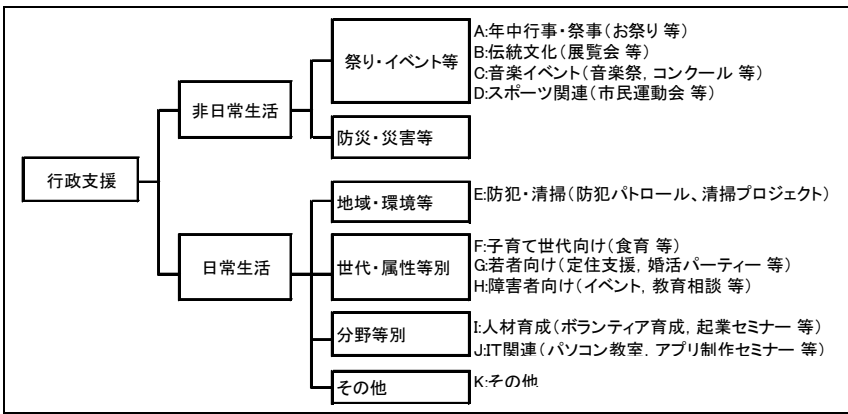

図 1 行政が行っている事業・支援の分類

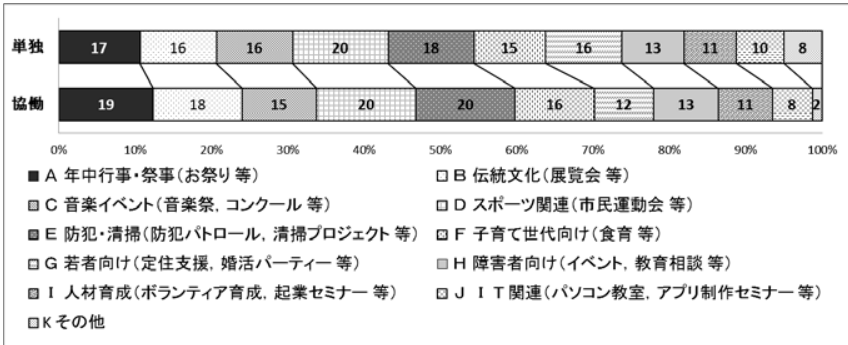

図 2 行政が行っている事業・支援 （MA, n=32）

表 3 行政が単独又は協働で行っている事業・支援「その他」の項目

\begin{tabular}{|c|c|c|}
\hline \multirow{8}{*}{ 独自 } & \multirow{4}{*}{ 交付金 } & コミュニティ活動育成事業補助金 \\
\hline & & 自治体に助成金を交付 \\
\hline & & 施設を設置し人的支援，地域資源活用及び課題解決のための財政支援 \\
\hline & & $\begin{array}{l}\text { 地縁にもとづく組織である「自治振興区」に対し、自治振興区振興交付金と } \\
\text { して交付 }\end{array}$ \\
\hline & \multirow[b]{3}{*}{ 推進 } & 地域おこし協力隊推進事業, 集落支援員推進事業 \\
\hline & & まちづくり自治会協議会設立に向けの取り組み \\
\hline & & $\begin{array}{l}\text { 高齢者支え合い, 子ども会育成, 交通安全母の会運営支援, 自主防災組 } \\
\text { 織活動支援など(ただし、厳密にいえばコミュニティ形成を目的に出支して } \\
\text { いるものではない) }\end{array}$ \\
\hline & $\begin{array}{l}\text { 推進 }+ \\
\text { 交付金 }\end{array}$ & 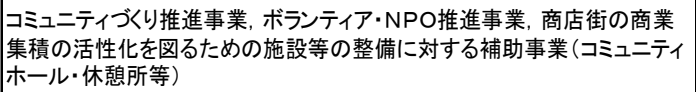 \\
\hline \multirow[b]{2}{*}{ 協働 } & 推進 & 自治会共創と協動のまちづくり事業 \\
\hline & $\begin{array}{l}\text { 推進+ } \\
\text { 交付金 }\end{array}$ & $\begin{array}{l}\text { 住民自治協議会設立支援事業, 市民協働のまちづくり活動応援補助事 } \\
\text { 業, 市民協働のまちづくり地域活性化施設等設備補助事業 }\end{array}$ \\
\hline
\end{tabular}

注) 行政側の判断により行政独自・協働に分類

清掃プロジェクト等） $11.2 \%<12.9 \%$ 等であった。“行政が単独で 行っている事業・支援” は, 若者や IT 関係など限られた人を対象 としており, “行政が市民または企業と協働で行っている事業・支援” は, 全ての地域住民を対象とすることが多く, 週に数回行き, 認知 度の高い地域の大型商業施設を利用して行政が事業・支援をしてい くことのメリットと効果を裏付けている。また，限られた人を対象 とした事業・支援も，多くの人の目に触れるところでの開催は，地 域住民に対して G: 若者向け（定住支援, 婚活パーティ等)のように, その地域で求められていることや, 時代に即した J:IT 関連 (パソコ ン教室，アプリ制作セミナー等）のように普及する役割も持つと思 われる。既成概念による対象範囲を広げる可能性も持つ。なお，「そ の他」の項目は，表 3 に示すように【交付金】【推進】【交付金十推 進】である。これらは，コミュニティづくりなどの地域のネットワ 
ーク支援のためのものが多い。

\section{2 行政による大型商業施設への共同出資 · 支援}

行政による大型商業施設への共同出資, 支援の提案項目を行政が 現在行っている事業・支援及び既往研究, 現地調查等 4 ～7) を参照 に次の 13 項目を設定し， 3.1 行政が行っている事業・支援により 得られた大分類に沿って図 3 に示す。(1) : 地域イベントを協㗢で企 画する『地域イベント支援』, (2) : 避難物資として行政が買取り配布 する『被災者・店舗支援の企画』，(3)：行政の派遣する人が駐在でき る『出張所』, (4)：休款スペースの『ミーティングスペース設備』, 提案(5): 市道として緑化整備する『通路の緑化整備』, (6) : 授乳室の 機能を持った『幼児子育てママのコミュニケーション空間』, (7): 行 政が派遣する栄養士による『食育支援の企画』, 提案(8): 栄養士のレ シピ紹介や食育相談を行うための『食育推進設備』, (9): 子供を預け 食事支援もできる『託児・団欒施設』, (10：通行人の多い場所一『児 童公園設置』, (11) : 健康意識の高い働き世代対象の『運動推進施設』, (12) : 高齢者対象の『リハビリコーナー設備』, (13): 制作物を展示でき る『制作・展示スペース』。

3.1 で示したように行政が行っている事業・支援の項目が多い ものは，「祭り・イベント等」「分野等別」であり， 3.2 の行政によ る大型商業施設への共同出資・支援では，「防災・災害等」，「地域・ 環境等」, 特に「世代・属性等別」の提案項目が増えている。災害, 少子高齢化の時代に即し, より日常生活における地域住民の属性ご とに対応したものとなっている。

これらの提案について, 行政が “行っている”, “行う予定”, “実 現は可能”, “実現不可能”, “未記入”についての比率を図 4 に示す。 行政が既に “行っている” 項目は多い順に, (13): 制作物を展示でき る『制作・展示スペース』: $12 \%$ ，(2)：避難物資として行政が買取 り配布する『被災者・店舗支援の企画』: $12 \%$ (“行う予定”も含む)， (1) : 地域イベントを協働で企画する『地域イベント支援』9\%，(3)： 行政の派遣する人が駐在できる『出張所』: 9\%, (4): 休款スペース の『ミーティングスペース設備』9\%(“行う予定”も含む)，(6)： 授乳室の機能を持った『幼児子育てママのコミュニケーション空間』 $6 \%$, (12): 高齢者対象の『リハビリコーナー設備』3\%であった。

3.1 の行政が行っている事業・支援に示すように, 行政が市民と または企業と行っている事業・支援の項目でもB:伝統文化（展覧会 等）の占める割合は多かったが，同\%にて(2)：避難物資として行政 が買取り配布する『被災者・店舗支援』の企画：12\%（“行う予定” も含む）があり，2011 年 3 月 11 日に発生した東北地方太平洋沖地 震の影響も見受けられた。表 4 の行政が単独又は協働で行っている 事業・支援「その他」の項目においても，行政が交付金や，地域活 性化を推進するための組織作りなどを実施していることは得られて いるが，(4)：休憩スペースの『ミーティングスペース設備』9\%（行 う予定も含む) のように具体的に大型商業施設にて実施している。 又, 大型商業施設自体が実施している例は見られるが, 行政が共同 出資，支援をしている(6) : 授乳室の機能を持った『幼児子育てママ のコミュニケーション空間』 $6 \%$, (12) : 高齢者対象の『リハビリコ 一ナー設備』 $3 \%$ であったことは，注目に值する。

“実現は可能”の項目では比率が多い提案に, (1): 地域イベント を協働で企画する『地域イベント支援』 $72 \%$, 13) : 制作物を展示で きる『制作・展示スペース』 $66 \%$ ，(6)：授乳室の機能を持った『幼

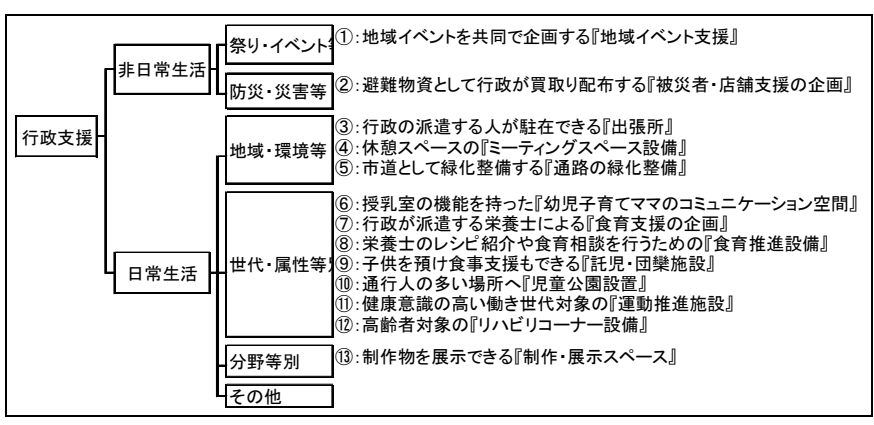

図 3 行政による大型商業施設への共同出資 - 支援の提案分類

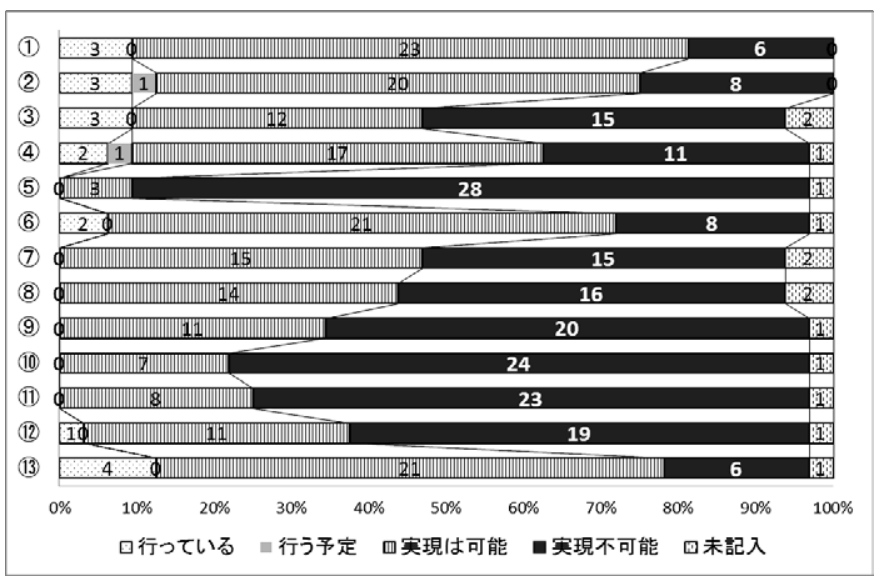

注1)

①地域イベントを共同で企画する『地域イベント支援』（8: 栄養士のレシビ紹介や食有相談を行うための『食育推進設備』

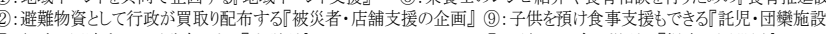

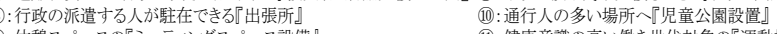

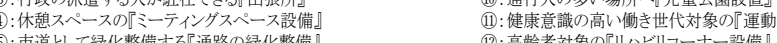

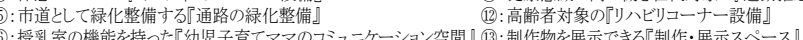

(7):行政が派遣寸る栄養士による能有支援の企画』

図 4 行政による大型商業施設への共同出資，支援の提案 $(\mathrm{SA}, \mathrm{n}=32)$

児子育てママのコミュニケーション空間』 $66 \%$ と従来の行政が行っ ているものがあげられているが，(2)：避難物資として行政が買取り 配布する『被災者・店舗支援の企画』63\%，(4): 休款スペースの『ミ ーティングスペース設備』53\%と，既に“行っている”，“行う予定” と同じような結果が得られた。

“実現不可能”の項目の多い提案は，提案(13)：市道として緑化整 備する『通路の緑化整備』 $88 \%$ ，10：通行人の多い場所一『児童公 園設置』 $75 \%$, (11) : 健康意識の高い働き世代対象の『運動推進施設』 $72 \%$ あっった。

(1) (13)以外の行政による大型商業施設への共同出資，支援の提案 については，＜買物弱者対策としてのスーパーへの支援＞があげら れた。

行政による大型商業施設への共同出資，支援についての意見を分 類したものを，表 4 に示す。大分類は「可能」「条件が合えば可能」 $「$ (現状) 不可能」「該当外」に分けられる。中分類は，「可能」が【既 成事実】【進行中】【検討】,「条件が合えば可能」が【可能（定義・ 条件による)】(大型商業施設との関係】「(現状）不可能」が【他部 署・施設対応】【人員問題】【経費問題】【条例不適格】【責任明確化】 【特定不可能】【行政支援不可】【不適格】，「該当外」が【対象大型 商業施設問題】に分けられた。

「該当外」は大型商業施設が無いなどが理由である。「条件が合え ば可能」「(現状) 不可能」については，行政の仕事内容や組織体制 
表 4 行政による大型商業施設への共同出資，支援の提案についての意見

\begin{tabular}{|c|c|c|c|}
\hline \multicolumn{4}{|r|}{ 提案項目 } \\
\hline 大分類 & 中分類 & 提案番号 & 詳細 \\
\hline \multirow[t]{5}{*}{ 可能 } & \multirow[t]{3}{*}{ 既成事実 } & (2) & 協定を結束している事例がある。 \\
\hline & & (4) & $\begin{array}{l}\text { 大型ショ゙ピングセンターの一角にそのようなスペースを設けている事例が } \\
\text { ある。 }\end{array}$ \\
\hline & & (5) & 通行環境については、開発協議の中で調整をしている。 \\
\hline & 進行中 & (2) & 琴在検討中。 \\
\hline & 検討 & (2) & 災害協定について検討可能と思 ${ }^{2}$ 。 \\
\hline \multirow[t]{4}{*}{$\begin{array}{l}\text { 条件が合 } \\
\text { えば可能 }\end{array}$} & \multirow[t]{3}{*}{\begin{tabular}{|l|} 
可能(定義· \\
条件による)
\end{tabular}} & $\begin{array}{l}\text { (3)(4)(6)(8)(12) } \\
\text { (11)(9) }\end{array}$ & 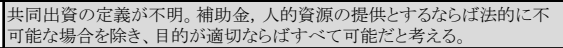 \\
\hline & & 9 & 既存の保育, 学童保育との機能分担, 調整が必要。 \\
\hline & & (i1) & 公園設備は利用者, 地域性等により広い観点で計画する必要がある。 \\
\hline & \begin{tabular}{|l|} 
大型商業施 \\
設との関倸
\end{tabular} & (7) & $\begin{array}{l}\text { いずれも不可能とまでは言わないが、スーパーとの関係を築くに至っていな } \\
\text { い。 }\end{array}$ \\
\hline \multirow{25}{*}{$\begin{array}{l}\text { (現状) } \\
\text { 不可能 }\end{array}$} & \multirow{5}{*}{$\begin{array}{l}\text { 他部署·施設 } \\
\text { 対応 }\end{array}$} & \multirow[b]{3}{*}{$(7)$} & コミュニティは公民館などがある \\
\hline & & & 食生活改善促進員が行っている。 \\
\hline & & & $\begin{array}{l}\text { 学校や公民館施設等で行っている。道の駅で料理教室を通した食育も実 } \\
\text { 施されている。 }\end{array}$ \\
\hline & & (3) & 別の専門施設で実施。 \\
\hline & & (12) & 公共施設等を活用して、各地の「サロン」が運営されている。 \\
\hline & 人員問題 & (3) & 人員は割けない。 \\
\hline & \multirow[t]{2}{*}{ 経費問題 } & $\begin{array}{l}\text { (2)(3)(4)(5) } 6 \\
\text { (7) (8)(9)(10)(11) } \\
\text { (12)(13) }\end{array}$ & 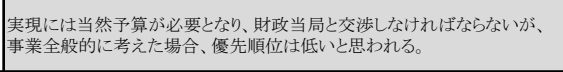 \\
\hline & & \begin{tabular}{|l|} 
(3)(4)(5)(6)(8) \\
(9)(10)(11)(12)
\end{tabular} & |支援はできるかもしれないが、出資は難しい。 \\
\hline & \multirow[b]{2}{*}{ 条例不適格 } & (10) & $\begin{array}{l}\text { 本市では条例で市有地を「児童遊園」としているため前例からみれば敷地 } \\
\text { 内といらことでは不可能であこと考える。 }\end{array}$ \\
\hline & & (5) & $\begin{array}{l}\text { 本市では条例で公有地，市有地を「市道」としているため前例から見れば } \\
\text { 地内といらことは不可能であると考える。 }\end{array}$ \\
\hline & 責任明確化 & (5)(10) & 設置者，管理者の責任を明確にしないと事故等の対応に困ると思う。 \\
\hline & 特定不可能 & (7) & 本市に44社のスーパーがあるが、特定できないと思う。 \\
\hline & \multirow{10}{*}{$\begin{array}{l}\text { 行政支援 } \\
\text { 不可 }\end{array}$} & (7) & 行政が民間の企画を行うことは不可能。 \\
\hline & & (7) & 民業として可能だと思う。 \\
\hline & & (1) & CSR，事業者の連携により可能だと思う。 \\
\hline & & \multirow[t]{2}{*}{ (1) } & $\begin{array}{l}\text { 地城自治会が民間と共同でイベントを行うことは可能であるが行政は介入 } \\
\text { できな。 }\end{array}$ \\
\hline & & & $\begin{array}{l}\text { 確かに人の集まる場所だが営利目的のスーパーと連携することは今は考え } \\
\text { ていない。 }\end{array}$ \\
\hline & & (2) & 行政が民間の企画赽行うことは不可能。 \\
\hline & & (8) & 民業で可能と思う。すでに地産地消の一環として実施されている。 \\
\hline & & (9)(3) & スーパー独自で実施。支援は不要。 \\
\hline & & (11) & 民業圧迫を䋰念する。 \\
\hline & & (5) & 該当スーパーが(市道として)寄付されるなら支援は可能。 \\
\hline & \multirow{3}{*}{ 不適格 } & (7) & 公益性が弱いように感じる。 \\
\hline & & (1) & おむしろい内容と思うが、スーパーで行う必然性が理解できない。 \\
\hline & & (2) & 避難所として機能させるのは困難だと思う。 \\
\hline \multirow{4}{*}{ 該当外 } & \multirow{4}{*}{\begin{tabular}{l|l} 
対象大型商 \\
業施設問題
\end{tabular}} & (1)(7) & 該当する施設がない。 \\
\hline & & (1)(5)(11) & 大規模なスーパーがない。 \\
\hline & & $\begin{array}{ll}\text { (3)(4)(6)(8)(9) } \\
\text { (11)(12)(3) }\end{array}$ & 店舗面積が狭いのでスーパーの確保が難しいと思う。（できればいいが） \\
\hline & & (10) & 般地がない。 \\
\hline \multicolumn{4}{|c|}{ 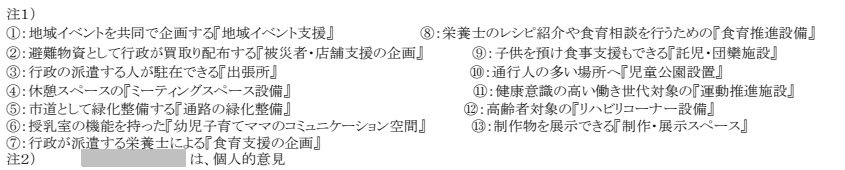 } \\
\hline
\end{tabular}

の概念を変更させること，条例などの規制枠，今後の調整を見込ん だら解決できる可能性を含んでいる。

\section{3 行政側のメリット}

仮に大型商業施設と共同出資，支援したときの行政側のメリット を，イ：毎日多くの人が集まる場所で地域コミュニティ形成の支援 ができる，口：新たな地域の核を作ることができる，八：地域住 民の生活満足度の向上に繋がる, 二：行政が共同出資, 又は支援し ていることを地域住民に幅広く知ってもらえる, ホ: 専門の施設 (公 園，託児施設など）を建てる必要性が少なくなる，へ：共同出資を することで行政が負担する費用が少なくなる，卜：大型商業施設と の関係を作ることができる, チ: 部署間の協力体制が生まれ, 様々 な面で情報の共有ができる，に分類し“考えられる”, “考えられな い”, “未記入”の比率を図 5 に示す。回答の多いものは次のように なった。口：新たな地域の核を作ることができる $84 \%$, イ：毎日 多くの人が集まる場所で地域コミュニティ形成の支援ができる $81 \%$ ，八：地域住民の生活満足度の向上に繋がる $78 \%$ であり，既 存の民間企業の大型施設に行政が共同出資することで，無駄な経費 の削減ができ，より地域住民にとっての支援になることを理解して

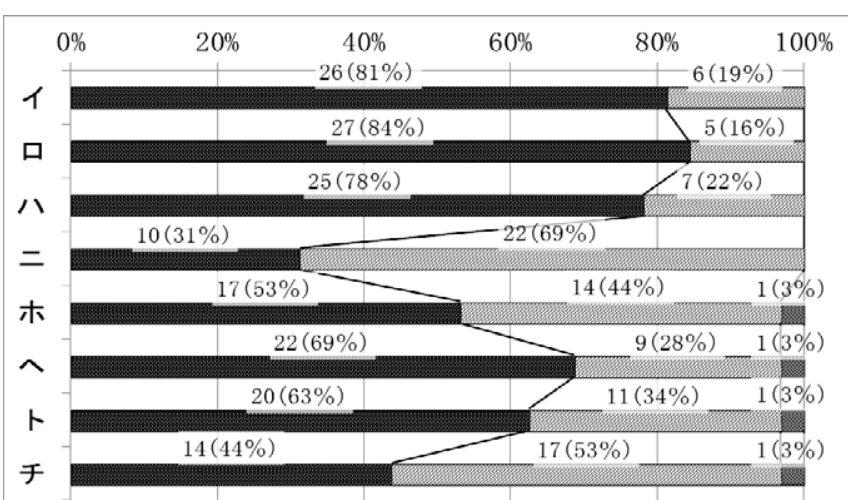

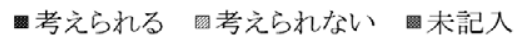

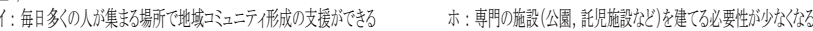

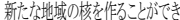

地域住民の生活满足度门向上飞慗加了

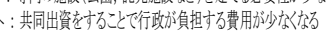

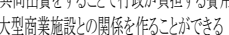

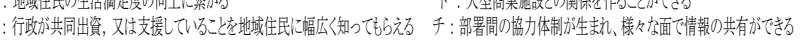

図 5 行政側のメリット $(\mathrm{SA}, \mathrm{n}=32)$

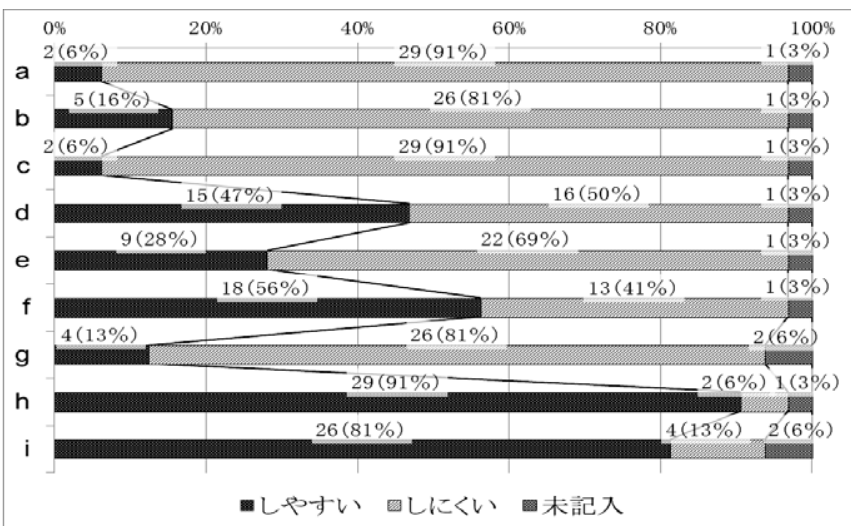

主1)

$\mathrm{a} ：$ 施設 (建物)の共同出資 (部分的な出資も含む) $\mathrm{b}$ ：設備の共同出資 (部分的な出資も含む)

：土地の共同出資(部分的な出資も含も) $\mathrm{d}$ : 支援金の支給

: 行政が所有する土地の提供 $\mathrm{f}$ : 人材派遣 (短期的: 数日)

: 人材派遣 (長期的:数 5 月, 定期的: 週数回) $\mathrm{h}$ : 行政HP等による情報発信

: 行政の持つ情報の提供による支援

図 6 行政による大型商業施設への共同出資，支援方法のしやすさ

(SA, n=32)

いるといえる。 $50 \%$ 以上の考えられない項目は，二：行政が共同出 資，又は支援していることを地域住民に幅広く知ってもらえる 69\%， チ：部署間の協力体制が生まれ，様々な面で情報の共有ができる $53 \%$ であった。

\section{4 行政による大型商業施設への共同出資, 支援方法のしやすさ}

行政による大型商業施設への共同出資，支援方法のしやすさを， $\mathrm{a}$ ：施設（建物）の共同出資（部分的な出資も含む）, $\mathrm{b}$ ：設備の共 同出資 (部分的な出資も含む), $\mathrm{c}$ ：土地の共同出資（部分的な出資 も含む)， d : 支援金の支給， e : 行政が所有する土地の提供， $\mathrm{f}$ : 人 材派遣（短期的：数日）, $\mathrm{g}$ : 人材派遣（長期的：数ヶ月，定期的： 週数回), $\mathrm{h}$ : 行政 $\mathrm{H}$ P 等による情報発信, i : 行政の持つ情報の提供 による支援に分類し，“しやすい”，“しにくい”，“未記入”の比率を 図 6 に示す。“しやすい”が $50 \%$ を超えるものは，h : 行政 H P 等に よる情報発信 $91 \%, \mathrm{i}$ : 行政の持つ情報の提供による支援 $81 \%, f$ : 人材派遣（短期的：数日），であった。反対に“しにくい”もので多 いものは, a : 施設 (建物) の共同出資（部分的な出資も含む） $91 \%$, $\mathrm{c}$ ：土地の共同出資（部分的な出資も含む） $91 \%, \mathrm{~b}$ ：設備の共同出 資（部分的な出資も含む） $81 \%, \mathrm{~g}$ ：人材派遣（長期的：数ヶ月， 
定期的 : 週数回） $81 \%$ で, 土地・建物・設備のハード名部分への共 同出資は難しい状況が得られた。また, 人材派遣についての短期は 良く，長期は難しい状況が得られた。

ここでは予算がかからない項目だけにしやすいと回答しており， 現状のハードルの高さ，根本的な行政のあり方の見直しが必要なこ とが垣間見られた。a〜i 以外の行政によるスーパーへの共同出資，支 援方法のしやすさについての新たな提案は得られなかった。

\section{5 大型商業施設が地域の核になることに繋がるか否か}

“共同出資，支援により大型商業施設が地域の核になることに繋 がるか否か”については図 7 に, “大型商業施設が地域の核になるか 否か”については図 8 に示した。“共同出資，支援により大型商業施 設が地域の核になることに繋がるか否か”については“繋がると思 う”が $66 \%$ と $2 / 3$ 以上の回答を得た。“大型商業施設が地域の核に なる否か”については，“核になると思う” $56 \%$ と半数以上の回答 を得た。

$2 つ$ 問いから大型商業施設は地域の核になると半数以上が考え, 行政が “共同出資, 支援” 寸ることにより，10\%も “大型商業施設 が地域の核になる”可能性が増すと考えられていることがわかった。

\section{4.まとめ}

大型商業施設が地域の核となるための行政支援に関して中国・四 国地方 9 県の各市役所を対象にアンケートを行った結果, 下記のこ とが得られた。

（1）“行政が単独で行っている事業・支援” は若者や IT 関係など 限られた人を対象としており, “行政が市民または企業と行って いる事業・支援” は，全ての地域住民を対象とすることが多い。 限られた人を対象とした事業・支援も多くの人が集まり多くの 人の目に触れるところでの開催は，その時代，その地域に求め られていることを地域住民に波及する効果がある。

（2）行政が既に“行っている” 項目は約 1 割前後, “実現は可能” は 5 割以上であり，(1)：地域イベントを協働で企画する『地域 イベント支援』，(2)：避難物資として行政が買取り配布する『被 災者・店舗支援の企画』，(3):行政の派遣する人が駐在できる『出 張所』, (4) : 休憩スペースの『ミーティングスペース設備』, (13): 制作物を展示できる『制作・展示スペース』，の項目である。

(3) “実現不可能” な項目の多い提案は, 提案(5) : 市道として緑化 整備する『通路の緑化整備』, (10) : 通行人の多い場所へ『児童公 園設置』，(11：健康意識の高い働き世代対象の『運動推進施設』 など，土地・建物・設備への支援である。

（4）大型商業施設と共同出資，支援したときの行政側のメリット は，イ：毎日多くの人が集まる場所で地域コミュニティ形成の 支援ができる，口：新たな地域の核を作ることができる，八： 地域住民の生活満足度の向上に繋がることであり，行政が地域 住民一の施策として求めていることである。

（5）行政による大型商業施設への共同出資，支援方法のしやすさ については, h: 行政 H P 等による情報発信, $\mathrm{i}:$ 行政の持つ情 報の提供による支援, $\mathrm{f}$ : 人材派遣（短期的：数日）など経費が 掛らないものである。反対に“しにくい”ものは，a：施設（建 物）の共同出資（部分的な出資も含む）, $\mathrm{c}$ ：土地の共同出資（部 分的な出資も含む), $\mathrm{b}$ : 設備の共同出資 (部分的な出資も含む), $\mathrm{g}$ : 人材派遣（長期的：数ヶ月，定期的：週数回）で, 土地・

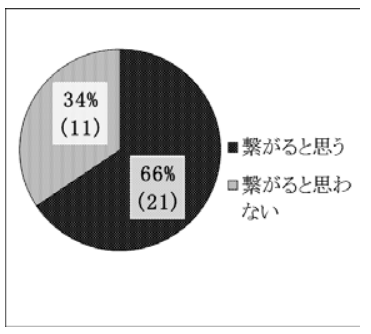

図 7 共同出資，支援により 大型商業施設が地域の核にな ることに繋がるか否か

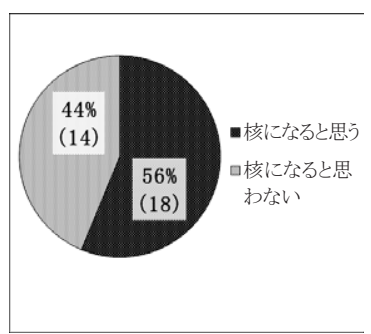

図 8 大型商業施設が地域の 核になるか否か
建物・設備などのハードな部分への共同出資は難しい状況が得

られ，提案項目の“実現不可能”な項目と一致した。

（6）大型商業施設が地域の核になることに慗がるか否かについて は，大型商業施設は地域の核になると半数以上が考えており， さらに“共同出資，支援”することにより，10\%も“大型商業 施設が地域の核になる”可能性が増すことが得られた。

行政が大型商業施設へ共同出資，支援することにより大型商業施 設が地域の核になることは理解されつつ，現在の行政の組織や条例 によってそれが阻止されているが，それをクリアすれば十分実現で きることが得られた。

大型商業施設だけではなく，大規模な私企業の施設など既存のも のに行政が支援し，私企業も一部を開放することによって，資源の 無䭾なく効果的に地域の住民を豊かにする方法の一つとして考える ことができるのではないだろうか。

\section{謝辞}

本研究は, 広島工業大学工学研究科環境学専攻修了の向井智之君 （株式会社ヤマダ・エスバイエルホーム）の協力を得た。 ここに感謝の意を示す。

\section{参考文献}

1）丁育華，近藤光男，渡辺公次郎：地方都市における消費者の買物意識と行 動の分析, 日本建築学会計画系論文集, 第 74 巻, 第 636 号, pp. 417-422, 2009.2

2）曽根陽子，香山愛理 : 高齢者層の交流の場としての近隣型小売商店の役割 -1960 年代のミニ開発住宅地における近隣コミュニケーションに関する 研究 その 2 -, 日本建築学会計画系論文集第 74 巻, 第 635 号, pp. 83-89, 2009. 1

3）向井智之，菅原辰幸，平田圭子：中国・四国地方の市役所を対象としたア ンケート調査による考察 一 地域密着型スーパーマーケットを核とする 地域コミュニティ形成に関する研究 - , 日本建築学会中国支部研究報告集, 第 35 巻, No. 0213, 2011.02

4）向井智之, 平田圭子 : スーパーマーケットの企画による地域との関わりに ついての研究, 日本インテリア学会大 21 回大会, pp. 47-48, 2009. 10

5）向井智之，平田圭子：店舗分類と現地調査から見るコミュニティ空間の在 り方について〜広島市内の地域密着型スーパーマーケットにおけるコミ ユニティ空間に関する研究（その1）～，日本建築学会大会学術講演梗概 集 $(\mathrm{E}-1)$, pp. 415-416, 2011. 10

6）平田圭子，向井智之：地域密着型スーパーマーケットのコミュニティ空間 となり得る場所について一広島市内の地域密着型スーパーマーケットに おけるコミュニティ空間に関する研究 その 1 - , 日本インテリア学会大 会 22 回大会, pp. 17-18,2010.10

7）向井智之，平田圭子：アンケート調査による休款スペースの利用状況につ いて一広島市内の地域密着型スーパーマーケットにおけるコミュニティ 空間に関する研究 その 2 -, 日本インテリア学会大会 22 回大会, pp. 19-20, 2010. 10 